\title{
Relationship Between Efficacy of Fusarium Head Blight Chemical Control and Deoxynivalenol Contamination on Wheat Kernels
}

\author{
Erlei Melo Reis ${ }^{1}$, Mateus Zanatta ${ }^{2} \&$ Andrea Camargo Reis ${ }^{2}$ \\ ${ }^{1}$ Escuela de Pósgrado Alberto Soriano, Universidade de Buenos Aires, Buenos Aires, Argentina \\ ${ }^{2}$ Instituto AGRIS, Passo Fundo, RS, Brazil \\ Correspondence: Erlei Melo Reis, Instituto AGRIS, Rua Miguel Vargas, 291 Passo Fundo, RS, CEP: 99025-380, \\ Brazil. E-mail: erleireis@upf.br
}

Received: June 7, $2020 \quad$ Accepted: July 27, $2020 \quad$ Online Published: August 15, 2020

doi:10.5539/jas.v12n9p227 URL: https://doi.org/10.5539/jas.v12n9p227

\begin{abstract}
In field experiment carried out in the 2018 growing season we tried to show the inverse relation between the efficacy of fusarium head blight (FHB) chemical control and the deoxynivalenol (DON) concentration in harvested kernels. The wheat cultivar Tbio Mestre was established under no-till in soybean residues and in winter rotation with black oats. The leaf rust and yellow spot control was performed during the vegetative stage by spraying the whole experimental area with three applications of epoxiconazole + krezoxim methyl $(0.7 \mathrm{~L} / \mathrm{ha})$. The most potent fungicides metconazole + pyraclostrobin $(1.0 \mathrm{~L} / \mathrm{ha})+$ mancozeb $(2.0 \mathrm{~kg} / \mathrm{ha})$, prothioconazole + trifloxystrobin $(0.4 \mathrm{~L} / \mathrm{ha})$ and pydiflumetofen $(1.0 \mathrm{~L} / \mathrm{ha})$ were compared to control FHB. Disease incidence in spikes, incidence in spikelets, or spikes severity, grain weight and yield were evaluated. DON concentration was. Using the most efficient technology available for FHB control, the hypothesis of the inverse relationship between disease intensity occurring naturally in spikes, and deoxinivalenol (DON) concentration in the harvested grains was confirmed. DON concentration in unsprayed grains was 3,675 and in the best treatments 821 to 1,067 ppb.
\end{abstract}

Keywords: Fusarium graminearum, fungicide, Gibberela zeae, mycotoxin, Triticum aestivum

\section{Introduction}

In the 2018 year the wheat (Triticum aestivum L.) Brazilian consumption was 11 million tons and the national production only 4,3 million tons. The difference between demand and production shows the great challenge of making the country self-sufficient (CONAB, 2018).

Producing wheat where environmental adversities are constant, as in South of Brazil, is not an easy task. The constraints are directly related to the excess of rains after flowering to cereal ripening. Wheat crop requires approximately $312-550 \mathrm{~mm}$ rain distributed throughout its cycle. South of the $24^{\circ} \mathrm{S}$ parallel, the normal from June to November is $944 \mathrm{~mm}$, therefore, much higher than the crop requirements (Westphalen, 1982).

Due to cultivars susceptibility and favorable environment some diseases limit the amount and quality of wheat production. Among them, fusarium head blight (FHB), caused mainly by Gibberella zeae (Schwein.) Petch., Anamorph Fusarium graminearum Schwab (Reunião de Pesquisa de Soja da Região Sul, 2016). FHB was first described by Smith in 1841, in the United States (Arthur, 1891), in Argentina in 1927, and in Brazil, in 1942 (Costa Neto, 1947).

Quantitative damages caused by FHB, after no-till has been widely used by growers can be as high as $39.8 \%$ (Casa et al., 2004, 2011). In addition to the quantitative damage, the qualitative due to the grains contamination by mycotoxins is equally important (Paul et al., 2007, 2018). There are reports showing that the reduction of mycotoxin content related to FHB chemical control, i.e., as control increases deoxynivalenol (DON) contamination decreases (Haidukowsky et al., 2016).

Gibberella zeae infective period, and its reflection on the FHB intensity, considering that inoculum is always available, is direct related to anthers continuous wetting period duration (Andersen, 1948; Brustolin et al., 2013; Reis \& Carmona, 2013). Thus, the predisposition period extends from the anthesis beginning (GS 60) to ripening (GS 87) (26). 
Work carried out in the field showed that the environmental conditions which determined the lowest heads incidence were $53.5 \mathrm{~h}$ of wetness and $16.9^{\circ} \mathrm{C}$ mean air temperature in this period. These conditions resulted in a $3.7 \%$ heads incidence. However, in the 22 to $27{ }^{\circ} \mathrm{C}$ thermal range and with 45 hours of continuous wetting resulted in $60 \%$ infected spikelets. This long head wetting period showed that the disease depends on post-anthesis rains and not dew (Brustolin et al., 2013). Moreover, the longer the post-infection wetting period, the greater the DON contamination (Cowger et al., 2009).

Report suggests that if weather conditions do not favor infection at early anthesis, then it is justified to delay spraying until rain is forecasted. In Southern Brazil, inoculum as ascospores are always present in the air all year around thus head wetting is determinant for infection (Reis, 1988). We have long known that weather (heads wetting duration) is the main factor determining infection. Without rain occurrence post-anthesis onset, which provides the duration of required wetting infection, disease does not occur. Without sufficient duration of wetting period there is no infection. Therefore, the best indicator to time the first fungicide spraying aiming at the FHB control is the rainfall forecast (Brustolin et al., 2013; Reis et al., 2013).

In recent years, fungicides have become an important component of FHB management strategies. The research identified potent fungicides (metconazole, prothioconazole), spray nozzles (Defy 3D) and spraying speed (8.5 $\mathrm{km} / \mathrm{h}$ ) that result in the best fungicide deposition on the heads sides (anthers), and especially the time of application after anthesis onset and before forecasted rain occurrence (Nicholson et al., 1999; Reis et al., 2013).

According to the Food and Agriculture Organization (FAO), it is estimated that $25 \%$ of food in the world is contaminated with mycotoxins. The National Sanitary Surveillance Agency (Anvisa, 2019) has established the maximum tolerated limits of mycotoxins, with increasingly restrictive levels. The DON, or vomitoxin, limit in wheat grains was 2,000 parts per billion (ppb). But, from 2019 on, for whole wheat and wheat bran, the permitted concentration was reduced from 1,250 ppb to 1,000 ppb (Anvisa, 2019).

In the current control situation, the best tactic to reduce DON below the tolerable concentration is to concentrate efforts in improving the effectiveness of the control with fungicides. Reports indicated that efficient fungicide spraying significantly reduces FHB intensity and DON levels and increased both yield and thousand kernel weight, when compared to untreated controls (Nicholson et al., 199). As shown, DON contamination in grains is directly related to FHB intensity (Blandino et al., 2006; Haidukowsky et al., 2005; Paul et al., 2018).

Great efforts have been made on the genetic improvement aiming at resistance to FHB, however, little progress has been achieved. Over the years of research aimed at improving chemical control, more potent fungicides, application technology aiming to improve the deposition on heads sides and the precise time of the first application showed that control of the incidence in ears of up to $80 \%$ were achieved (Reis \& Carmona, 2013).

FHB chemical control generally has poor efficacy and mostly susceptible cultivars are grown, under this condition, therefore, the toxin risk is high. Therefore, a feasible strategy for DON reduction in wheat grains is to focus on the improvement of the disease chemical control efficacy in commercial field crops (Nicholson et al., 1999; Paul et al., 2007).

The hypothesis formulated in our work is that the more efficient the control resulting from the application of fungicides, the lower the DON content in the harvested kernels.

Using the best available technology for FHB control, the objective of this work was to confirm the relationship between FHB intensity and the DON content in the harvested grains.

\section{Method}

\subsection{Experimental Site}

Experiment was carried out at Fazenda Carvalho, Passo da Areia district, Km 169, 324 RS road, Passo Fundo, RS state, latitude $28^{\circ} 12^{\prime} 18^{\prime \prime} \mathrm{S}$, longitude $52^{\circ} 29^{\prime} 45^{\prime \prime} \mathrm{W}$ and altitude $660 \mathrm{~m}$ a.s.l. during June to November, 2018.

\subsection{Wheat Cultivar and Cropping System}

Wheat Tbio Mestre cultivar was sown on July $13^{\text {th }}, 2018$ in soybean residues and under no till seeding 320 viable $\mathrm{seed} / \mathrm{m}^{2}$, and in winter rotation with black oats (Avena strigosa Schreb.).

Field was managed in terms of fertilizer application, and pest management according to Zadoks et al. (1974) throughout the experimental area, including the control plots, and independently of FHB control. The first application was performed when the economic damage threshold reached $6 \%$ LI (leaves incidence), with the coformulation epoxiconazole $(127 \mathrm{~g} / \mathrm{L})+$ kresoxim methyl $(125 \mathrm{~g} / \mathrm{L})(0.7 \mathrm{~L} / \mathrm{ha})$. A second and third sprayings were performed at 15 days intervals. 


\subsection{Fungicides and Rates for FHB Control}

(a) Metconazole $(80 \mathrm{~g} / \mathrm{L})+$ pyraclostrobin $(130 \mathrm{~g} / \mathrm{L}) 1.0 .+$ mancozeb $(750 \mathrm{~g} / \mathrm{L}) 2.0 \mathrm{~kg} / \mathrm{ha}$, (b) prothioconazole $(175 \mathrm{~g} / \mathrm{L})$ trifloxystrobin $(150 \mathrm{~g} / \mathrm{L})-0.4 \mathrm{~L} / \mathrm{ha}$, and $(\mathrm{c})$ pydiflumetofen $(200 \mathrm{~g} / \mathrm{L})-1.0 \mathrm{~L} / \mathrm{ha}$, totalizing five treatments by the addition of one unsprayed.

\subsection{Adjuvant}

A silicone spreader (Silwet) $0.04 \mathrm{~L} /$ ha was used to improve heads coverage.

\subsection{Time of First Spraying for FHB Control}

The fungicide application was performed when, after the anthesis beginning and before occurrence of a predicted rainfall during the crop predisposition period. Rainfall forecast were daily followed according CPTC/INPE reports. When there was rain forecast for the next 24-72 hours, the fungicides were sprayed before the event onset. A second spraying, considering a 11-days protection period, was performed before new forecasted rain.

\subsection{Disease Assessment}

The treatments effects on FHB intensity, were evaluated (GS 26) collecting all heads in a $5.0 \mathrm{~m}$ long row, in the center of each plot, and in the laboratory, the spike incidence and severity (spikelet incidence) were determined. It was considered infected the spike that had, at least, a white spikelet with white creepy awns. Control was calculated relating heads incidence, severity and FHB index (FHBI) in each treatment with the intensity in non-sprayed treatment. To appraise the overall disease intensity, heads incidence and head severity were integralized as follow: $\mathrm{FHBI}=(\mathrm{HI} \times \mathrm{SS}) / 100$, where, $\mathrm{HI}=$ head incidence and $\mathrm{SS}=$ spikelet severity.

\subsection{Grain Yield}

At the physiological maturation (GS 94), $14.4 \mathrm{~m}^{2}$ plots were harvested with a research machine, grains cleaned, weighed and yield estimated in $\mathrm{kg} / \mathrm{ha}$.

\subsection{DON Contamination}

A 200g kernels sample, from each plot, was sent to Instituto Samitec (www.samitec.com.br) laboratory Faxinal da Palma, Santa Maria, RS for DON quantification.

\subsection{Experimental Design and Statistical Analysis}

Experimental design was a complete random blocks. Data were submitted to ANOVA, and means compared by Tukey teste, and regression.

\section{Results and Discussion}

The wheat cultivar Tbio Mestre is susceptible to leaf rust, to yellow spot and to scab. The favorable environment, with frequent rains and temperature of $20-25{ }^{\circ} \mathrm{C}$, resulted in the development of diseases natural epidemics (Sutton, 1982; Brustolin et al., 2013).

Control of leaf diseases was independent of FHB and performed in the whole experimental area including the control plots. Thus, during the vegetative phase three fungicide applications were done at GS 25, 31, and 49.

Since the presence of DON is a limiting factor in the wheat industrialization, the most feasible measure for its reduction below the tolerable concentration is to improve the chemical control. In this sense, there has been progress in application technology such as identification of potent fungicides (metconazole and prothioconazole), Defy 3D nozzles, equipment speed $8.5 \mathrm{~km} / \mathrm{h}$ and, mainly, the time of application: after the onset of anthesis and before the occurrence of predicted rainfall.

The first spraying for FHB control was performed on October $06^{\text {th }}, 2018$, with $20 \%$ anthesis (GS 61) and predicted rain came on October $7^{\text {th }}$, 2018, resulting in spikes continuous wetting for seven days totalizing 91,4 $\mathrm{mm}$ rain. Second spraying was performed 11 days later on October $17^{\text {th }}, 2018$ at GS 68. Predicted rain started on October $18^{\text {th }}$ lasting two days totalizing $52.5 \mathrm{~mm}$. This timing criterion has been practical and accurate based on the rain forecast reports available in the media for wheat growers. However, a limiting factor is the operational capacity available at the farm to spray the entire area before rainfall occurs.

The interaction between temperature and duration of heads wetting with direct effect on infection, resulted in a higher natural occurrence of spike incidence, and severity in non-sprayed plots.

There were statistically differences among treatments for both head and spikelet incidence highlighting the pydiflumetofen fungitoxicity. The FHB ears incidence was 4.14 times higher than in spikelets (Figure 1). 


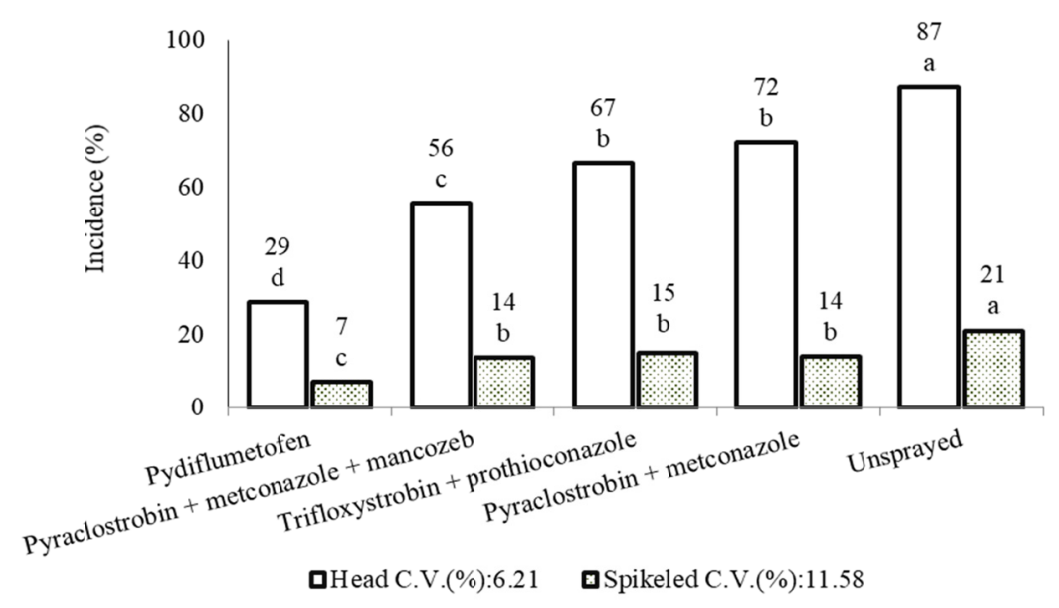

Figure 1. Effect of treatments on FHB incidence on wheat heads and spikelets

The control of FHB was the highest for FHB index, intermediate for spikelet incidence and the lowest for ear incidence. The best control was performed by pydiflumetofen considering ear and spikelet incidence as well for FHB index. Most of the control reports showed FHB efficacy less than 50\% (Paul et al., 2008) and with this new molecule can be higher than $80 \%$. Control by pyraclostrobin + metconazole was similar to trifloxystrobin + prothioconazole (Figure 2).

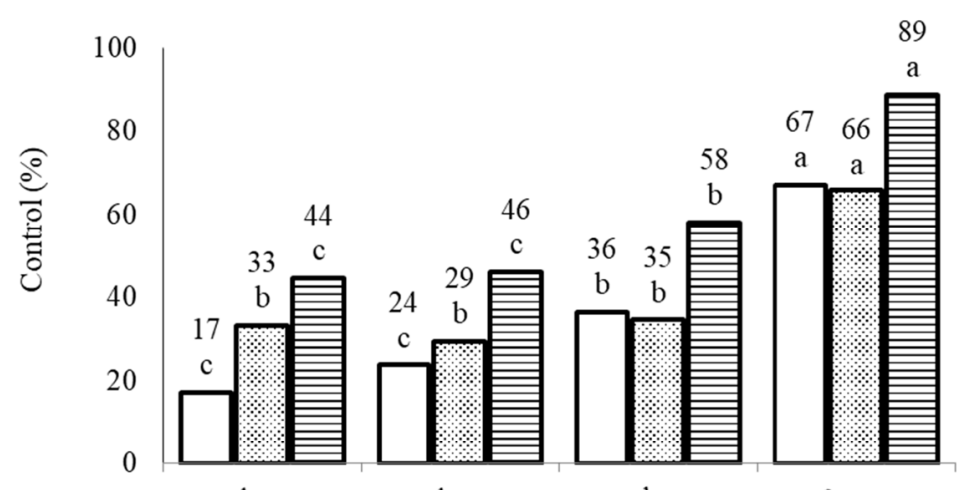

Pyraclostrobin + metconazole
Trifloxystrobin + prothioconazole
Pyraclostrobin + metconazole + mancozeb

$$
\text { 口Incidence C.V.(\%): } 13.99 \text { aSeverity C.V.(\%): } 12.49 \text { aIndex C.V.(\%): } 10.01
$$

Figure 2. Effects of treatments on FHB control of wheat heads incidence, heads severity and on FHB index

FHB is disease of ears reducing the quality by the direct attack on the grains or indirect by the rachis colonization. Therefore, there was a significant effect of its control on grain weight (Figure3). 


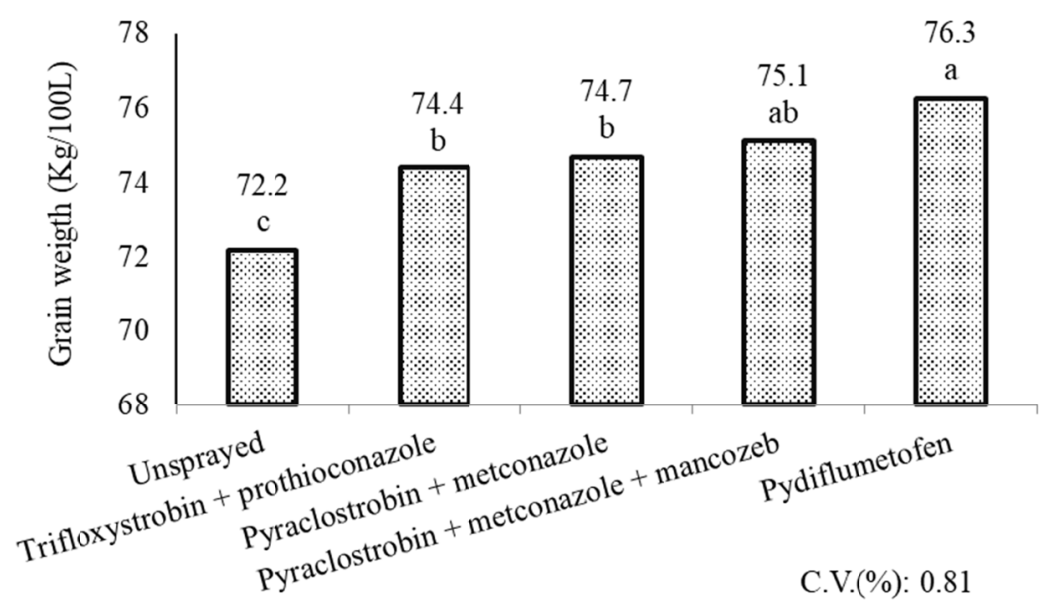

Figure 3. Effect of treatments on wheat grain weight $(\mathrm{kg} / 100 / \mathrm{L})$

Regarding grain yield there was a quantitative damage of $1,606 \mathrm{~kg} / \mathrm{ha}$ comparing the unsprayed treatment with pyndiflumetofen (Figure 4).

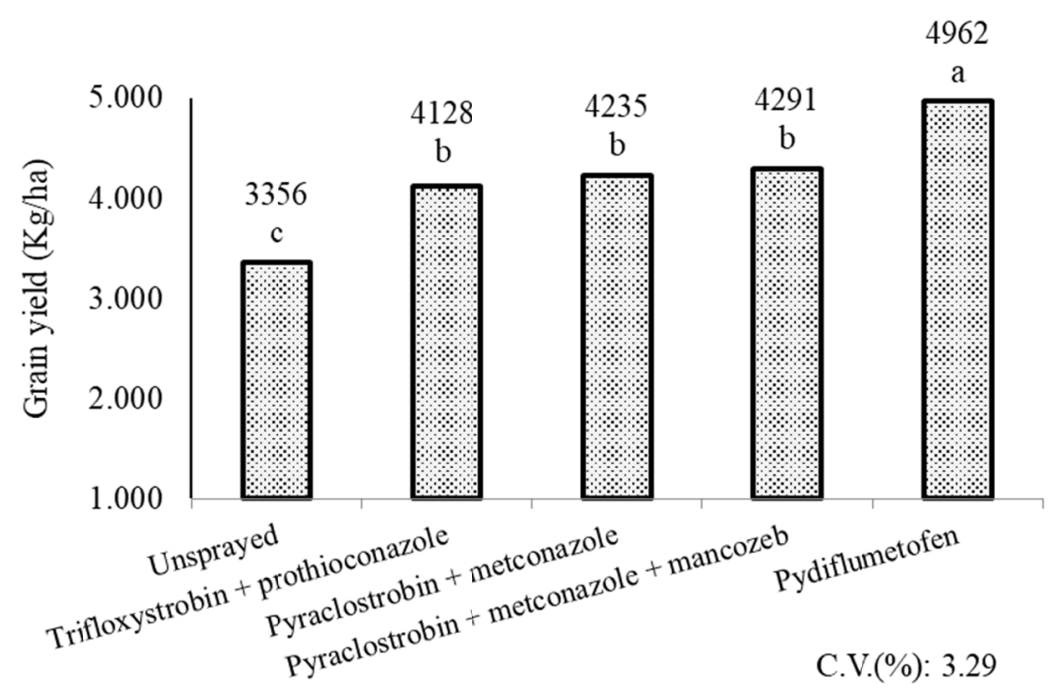

Figure 4. Effect of treatments on wheat grain yield

In addition to the fungicidal effect, mancozeb can show a nutritional effect on wheat plants by supplying manganese, therefore, although there was no statistical difference among treatments (trifloxystrobin + prothioconazole; pyraclostrobin + metconazole; pyraclostrobin + metconazole + mancozeb), except for pyndiflumetofen increase in grain yield may be due such effect. Furthermore, regarding mancozeb our work confirms previous report that the addition of mancozeb, increases not only FHB but also leaf blights control (Reis \& Floss, 1980; Reis et al., 2020).

The DON concentration in the unsprayed plots was $3,675 \mathrm{ppb}$, higher than the limit established para ANVISA of $1,000 \mathrm{ppb}$. Concentration of $2,350 \mathrm{ppb}$ was detected in plots sprayed with prothioconazole + trifloxystrobin and for pydiflumetofen $(1,067)$, pyraclostrobin + metconazole $(879)$, and pyraclostrobin + metconazole + mancozeb $(821 \mathrm{ppb})$ without statistical differenced among the last three (Figure 5). 


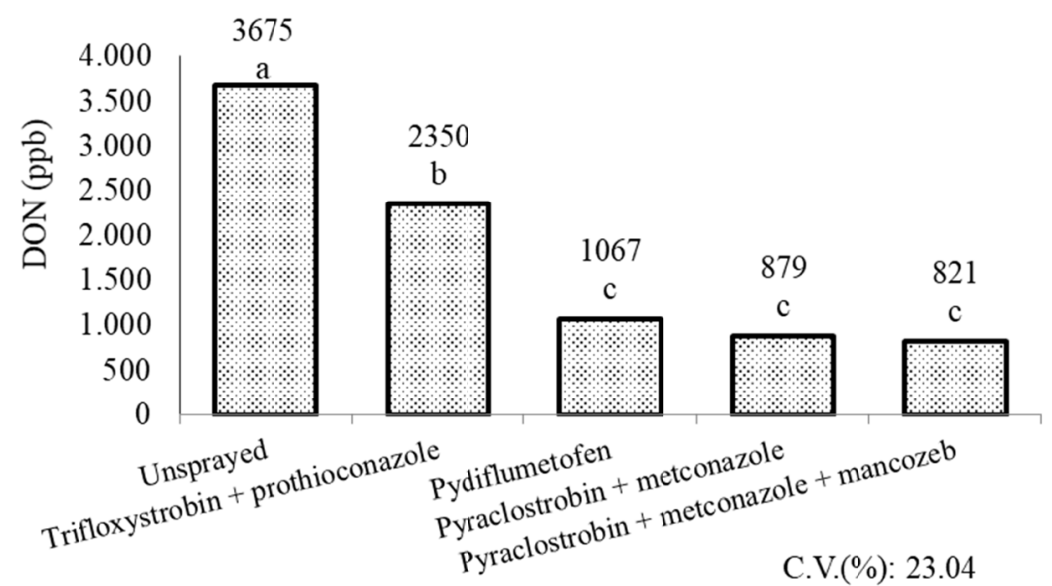

Figure 5. Effect of treatments on DON concentration

In response to efficacy variation of the fungicide treatments, a FHBI and DON gradient was generated. There was a linear DON increase of 32.296 ppb for every $1 \%$ FHB index increase (Figure 6).

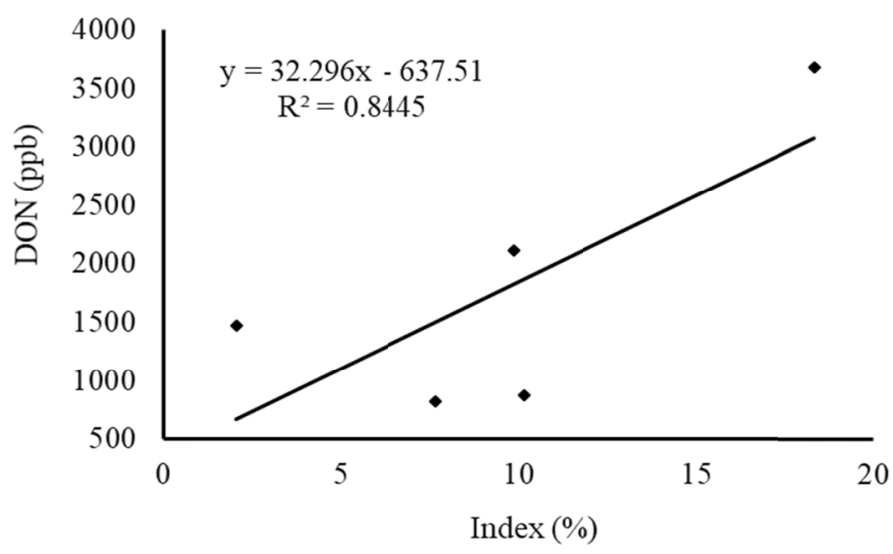

Figure 6. Relationship between DON concentration in wheat kernels and FHB index

Among treatments, trifloxystrobin + prothioconazole $(0.4 \mathrm{~L} / \mathrm{ha})$ showed DON concentration higher than pyraclostrobin + metconazole $(1.0 \mathrm{~L} / \mathrm{ha})$ with double dose.

There are reports showing that metconazole and prothioconazole are the best $\left(\mathrm{IC}_{50}<0.01 \mathrm{mg} / \mathrm{L}\right)$ compounds to control of F. graminearum (Paul et al., 2007, 2018). In our work the mix prothioconazole + trifloxystrobin showed not the best control and corresponding DON reduction. On the other hand, it has been shown that QoI fungicides, such as azoxystrobin, increases DON concentration (Ellner, 2005; Nicholson et al., 1999), but not specific report was found for pyraclostrobin and trifloxystrobin and others QoIs.

It is likely that the little efficient results obtained with prothioconazole + trifloxystrobin and metconazole + pyraclostrobin were due to lower dose $(0.4 \mathrm{~L} / \mathrm{ha})$ and to the presence of QoIs in their formulations. If we had used the DMIs alone, they could perform better. Unfortunately, the prothioconazole + tebuconazole (i.e., Prossaro), as available in other countries, but not available in the Brazilian market which has been tested in FHB with good control. Tebuconazole should not be replaced by a QoI for FHB control.

Therefore, it can be inferred that formulations containing QoIs may result in lower efficiency. In order to further improve FHB control, metconazole and prothioconazole formulations, the most potent, should not contain QoIs as is currently occurring. And in the future, pyndiflumetofen, the most potent in our work should not contain QoIs as future partners. Following the indications of Fungicide Action Committee (FRAC), this carboxamide should contain a multisite in the preformulated ready liquid mixture to maintain effective long life.

The performance of prothioconazole + trifloxystrobin $(0.4 \mathrm{~L} / \mathrm{ha})$ can be improved by dose increasing considering $1.0 \mathrm{~L} /$ ha metconazole + pyraclostrobin dose. 
It was accepted the hypothesis that contamination of DON in wheat grains is inversely proportional to the efficacy of FHB control confirming previous reports. Best treatments did not eliminate DON but reduced to values below the maximum tolerated level (Anvisa, 2019). Research should therefore be concentrated on further improving the efficacy of FHB control.

Beside fungicide efficacy (potent fungicides, spraying technology and timing for first spraying), varietal resistance is also an important component of efficient control of FHB in the field. High susceptible cultivars should be withdrawn from the wheat technical recommendations (Snijders, 1990).

Our results are in agreement with other works carried out on a large number of uniform fungicide studies in the field proving the effectiveness of some triazole-fungicides, including prothioconazole, for FHB and DON control in wheat (Paul et al., 2007, 2008). Our data also agree with recent investigations regarding the relationship between FHB disease and yield, showing a negative correlation between these two parameters (Nicholson et al, 1999; Paul et al., 2007, 2008).

Therefore, metconazole and prothioconazole treatments, alone or in combination with QoI, and mancozeb, and tolerant cultivars, are a useful tool for farmers to minimize Fusarium infection and to reduce DON levels in harvested grains, ensuring at the same time higher yields and grain quality compared to other fungicides treatments (Wegulo et al., 1982).

Our results provide useful information for wheat protection programs against toxigenic fungi responsible for FHB disease and the consequent DON accumulation in grains, particularly in those seasons in which environmental conditions could be favorable to cause FHB severe epidemics such as in Southern Brazil.

\section{References}

Andersen, A. L. (1948). The development of Gibberella zeae head blight of wheat. Phytopathology, 38, $595-611$.

Anvisa. (2019). Resolução da Diretoria Colegiada-RDC $N^{\circ} 138$, de 8 de Fevereiro de 2017 (Publicada no DOU no 29, de 9 de Fevereiro de 2017). Ministério da Saúde-MS Agência Nacional de Vigilância Sanitária. Retrieved from January 5, 2019, http://portal.anvisa.gov.br/documents/10181/3219534/RDC_138_2017_. $\mathrm{pdf} / \mathrm{b} 36 \mathrm{e} 60 \mathrm{~b} 0-5112-43 \mathrm{dc}-9142-932 \mathrm{f502fc46b}$ ?version=1.0

Arthur, J. C. (1891). Wheat scab. Bulletin of the Agricultural Experiment Station of Indiana. Purdue University, Lafayette, 2(36), 129-132.

Blandino, M., Minelli, L., \& Reyneri, A. (2006). Strategies for chemical control of Fusarium head blight: Effect on yield, alveographyc parameters and deoxynivalenol contamination in winter wheat grain. European Journal of Agronomy, 25, 193-201. https://doi.org/10.1016/j.eja.2006.05.001

Brustolin, R., Zoldan, S. M., Reis, E. M., Zanatta, T., \& Carmona, M. (2013). Weather requirements and rain forecast to time fungicide application for Fusarium head blight control in wheat. Summa Phytopathologica, 39(4), 248-251. https://doi.org/10.1590/S0100-54052013000400003

Casa, R. T., \& Kühnem, Jr. P. R. (2011). Danos causados nos hospedeiros. In E. M. Reis (Org.), Seminário sobre giberela em cereais de inverno (pp. 73-86). Passo Fundo, Berthier, Passo Fundo.

Casa, R. T., Reis, E. M., Blum, M. M. C., Bogo, A., Scheer, O., \& Zanata, T. (2004). Damage caused by infection with Gibberella zeae in wheat. Fitopatologia Brasileira, 29, 289-293. https://doi.org/10.1590/S0100-41582 004000300008

CONAB. (2018). Trigo Abril de 2018. Retrieved December 28, 2018, from file://C:/Users/User/Downloads/ TrigoZ-ZAnaliseZMensalZ-Zabril-2018\%20(1).pdf

Costa Neto, J. P. (1947). Parasitas de plantas cultivadas no Rio Grande do Sul (p. 21). Porto Alegre, Secretaria de Estado dos Negócios da Agricultura, Indústria e Comércio.

Cowger, C., Patton-Özkurt, J., Brown-Guedira, G., \& Perugini, L. (2009). Post-anthesis moisture increased Fusarium head blight and deoxynivalenol levels in North Carolina winter wheat. Phytopathology, 99, 320-327. https://doi.org/10.1094/PHYTO-99-4-0320

Ellner, F. M. (2005). Results of long-term field studies into the effect of strobilurin containing fungicides on the production of mycotoxins in several wheat varieties. Mycotoxin Research, 21, 112-115. https://doi.org/ 10.1007/BF02954432

Haidukowski, M., Pascale, M., Perrone, G., Pancaldi, D., Campagna, C., \& Visconti, A. (2005). Effects of fungicides on the development of Fusarium head blight, yield and deoxynivalenol accumulation in wheat 
inoculated under field conditions with Fusarium graminearum and Fusarium culmorum. Journal of the Science of Food and Agriculture, 85, 191-198. https://doi.org/10.1002/jsfa.1965

Nicholson, P., Turner, J. A., Jenkinson, P., Jennings, P., Stonehouse, J., Nuttall, M., ... Thomsett, M. (1999). Maximizing control with fungicides of Fusarium ear blight (FEB) to reduce toxin contamination of wheat. Project Report No. 297. Home-Grown Cereals Authority (HGCA).

Paul, P. A., Bradley, C. A., Madden, L. V., Lana, F. D., Bergstrom, G. C., Dill-Macky, R., ... Ruden, K. (2018). Effects of pre- and post-anthesis applications of demethylation inhibitor fungicides on fusarium head blight and deoxynivalenol in spring and winter wheat. Plant Disease, 102(12), 2500-2510. https://doi.org/10.1094/ PDIS-03-18-0466-RE

Paul, P. A., Lipps, P. E., Hershman, D. E., McMullen, M. P., Draper, M. A., \& Madden, L. V. (2007). A quantitative review of tebuconazole effect on Fusarium head blight and deoxynivalenol content in wheat. Phytopathology, 97, 211-220. https://doi.org/10.1094/PHYTO-97-2-0211

Paul, P. A., Lipps, P. E., Hershman, D. E., McMullen, M. P., Draper, M. A., \& Madden, L. V. (2008). Efficacy of triazole-based fungicides for Fusarium head blight and deoxynivalenol control in wheat: A multivariate metanalysis. Phytopathology, 98, 999-1011. https://doi.org/10.1094/PHYTO-98-9-0999

Reis, E. M. (1988). Quantificação de propágulos de Gibberella zeae no ar através de armadilhas de esporos. Fitopatologia Brasileira, 13(4), 324-327.

Reis, E. M., \& Carmona, M. (2013). Integrated disease management of Fusarium head blight. In T. M. A. Magliano, \& S. N. Chulze (Eds.), Fusarium head blight in Latin America (pp. 159-173). Dordrecht, Springer Science. https://doi.org/10.1007/978-94-007-7091-1_10

Reis, E. M., \& Floss, E. L. (1980). Efeito nutritivo de fungicidas carbamatos em trigo (Triticum aestivum L.). Summa Phytopathologica, 6, 116-122.

Reis, E. M., Zanatta, M., \& Forcelini, C. A. (2019). Addition of mancozeb to the fungicide mixtures DMI + QoI and SDHI + QoI on the control of wheat leaf blights. Summa Phytopathologica, 45(1), 23-27. https://doi.org/10.1590/0100-5405/179192

Reunião de Pesquisa de Soja da Região Sul. (2016). Indicações Técnicas Para a Cultura da Soja no Rio Grande do Sul e em Santa Catarina, Safras 2016/2017 e 2017/2018. Passo Fundo, RS: Editora Universidade de Passo Fundo.

Snijders, C. H. A. (1990). Fusarium head blight and mycotoxin contamination of wheat, a review. Netherlands Journal of Plant Pathology, 96, 187-198. https://doi.org/10.1007/BF01974256

Sutton, J. C. (1982). Epidemiology of wheat head blight and maize ear rot caused by Fusarium graminearum. Canadian Journal of Plant Pathology, 4(2), 195-209. https://doi.org/10.1080/07060668209501326

Wegulo, S. N., Bockus, W. W., Hernandez Nopsa, J., De Wolf, E. D., Eskridge, K. M., Peiris, K. H. S., \& Dowell, F. E. (2011). Effects of integrating cultivar resistance and fungicide application on Fusarium head blight and deoxynivalenol in winter wheat. Plant Disease, 95(5), 554-560. https://doi.org/10.1094/PDIS-07-10-0495

Westphalen, S. L. (1982). Evapotranspiração de uma cultivar precoce de trigo (Triticum aestivum L.) através de evapotranspirômetro "tipo thorthwaite". I. Relações com Evaporação do Tanque Classe A e Radiação Solar Global. Reuniao Nacional de Pesquisa de Trigo, 12, Cascavel, PR. Solos, ecologia, fisiologia e práticas culturais (pp. 68-79). IPAGRO, Porto Alegre.

Zadoks, J. C., Chang, T. T., \& Konzak, C. F. (1974). A decimal code for the growth stages of cereals. Weed Research, 14, 415-421. https://doi.org/10.1111/j.1365-3180.1974.tb01084.x

\section{Copyrights}

Copyright for this article is retained by the author(s), with first publication rights granted to the journal.

This is an open-access article distributed under the terms and conditions of the Creative Commons Attribution license (http://creativecommons.org/licenses/by/4.0/). 